\title{
GABA Receptors Inhibited by Benzodiazepines Mediate Fast Inhibitory Transmission in the Central Amygdala
}

\author{
Andrew J. Delaney and Pankaj Sah \\ Division of Neuroscience, John Curtin School of Medical Research, Australian National University, \\ Canberra ACT 2601, Australia
}

The amygdala is intimately involved in emotional behavior, and its role in the generation of anxiety and conditioned fear is well known. Benzodiazepines, which are commonly used for the relief of anxiety, are thought to act by enhancing the action of the inhibitory transmitter GABA. We have examined the properties of GABA-mediated inhibition in the amygdala. Whole-cell recordings were made from neurons in the lateral division of the central amygdala. Application of GABA evoked a current that reversed at the chloride equilibrium potential. Application of the GABA antagonists bicuculline or SR95531 inhibited the GABAevoked current in a manner consistent with two binding sites. Stimulation of afferents to neurons in the central amygdala evoked an IPSC that was mediated by the release of GABA. The $\mathrm{GABA}_{\mathrm{A}}$ receptor antagonists bicuculline and picrotoxin failed to completely block the IPSC. The bicuculline-resistant IPSC was chloride-selective and was unaffected by $\mathrm{GABA}_{\mathrm{B}}$-receptor antagonists. Furthermore, this current was insensitive to modulation by general anesthetics or barbiturates. In contrast to their actions at $\mathrm{GABA}_{\mathrm{A}}$ receptors, diazepam and flurazepam inhibited the bicuculline-resistant IPSC in a concentrationdependent manner. These effects were fully antagonized by the benzodiazepine site antagonist Ro15-1788. We conclude that a new type of ionotropic GABA receptor mediates fast inhibitory transmission in the central amygdala. This receptor may be a potential target for the development of new therapeutic strategies for anxiety disorders.

Key words: $G A B A_{C}$; fear; anxiety; diazepam; bicuculline; amygdala
GABA is the major inhibitory transmitter in the mammalian CNS (Nicoll et al., 1989). As with many other types of receptor, two broad types of GABA receptor are recognized: ionotropic ligandgated channels and metabotropic G-protein-coupled receptors. Ionotropic GABA receptors are further subdivided into the bicuculline-sensitive $\mathrm{GABA}_{\mathrm{A}}$ receptors (MacDonald and Olsen, 1994; Johnston, 1996a) and the bicuculline-insensitive $\mathrm{GABA}_{\mathrm{C}}$ receptors (Qian and Dowling, 1994; Bormann and Feigenspan, 1995). GABA $_{A}$ receptors gate a chloride ionophore and have modulatory binding sites for benzodiazepines, barbiturates, and anesthetics, all of which potentiate the response to GABA (MacDonald and Olsen, 1994; Johnston, 1996a). These receptors are potently inhibited by the competitive antagonists bicuculline and SR95531 and the plant alkaloid picrotoxin (Sieghart, 1995).

$\mathrm{GABA}_{\mathrm{A}}$ receptors are assembled from a large family of which fifteen members have so far been identified: $6 \alpha, 4 \beta, 3 \gamma, 1 \delta$, and $1 \epsilon$ (Barnard et al., 1998). Heterologous expression of different subunits has shown that functional GABA receptors can form as homomers or as heteromultimers of different subunits. However, most $\mathrm{GABA}_{\mathrm{A}}$ receptors in the CNS are thought to contain both $\alpha$ and $\beta$ subunits, with one or more of the $\gamma, \delta$, or $\epsilon$ subunits (Barnard et al., 1998). The subunit combination of a particular GABA receptor determines its pharmacological properties (Cos-

\footnotetext{
Received June 1, 1999; revised July 30, 1999; accepted Sept. 1, 1999.

This work was supported by grants from the National Health and Medical Research Council of Australia. P.S. is a Charles and Sylvia Viertel Senior Medical Research Fellow. We thank Prof. Graham Johnston for discussion throughout the course of this study and for providing us with several compounds. We thank John Bekkers, Rowland Taylor, and Luli Faber for comments on this manuscript.

Correspondence should be addressed to Pankaj Sah, Division of Neuroscience, John Curtin School of Medical Research, GPO Box 334, Canberra ACT 2601, Australia. E-mail: pankaj.sah@anu.edu.au.

Copyright (c) 1999 Society for Neuroscience 0270-6474/99/199698-07\$05.00/0
}

ta, 1998; MacDonald and Olsen, 1994). For example, amplification of GABA action by benzodiazepines is only seen in receptors that contain one of $\alpha 1, \alpha 2, \alpha 5$ subunits and either a $\gamma 2$ or a $\gamma 3$ subunit. Receptors that contain $\alpha 4, \alpha 6$, or $\gamma 1$ are unaffected by benzodiazepines (MacDonald and Olsen, 1994; Costa, 1998).

$\mathrm{GABA}_{\mathrm{C}}$ receptors also gate a chloride channel, but they are not blocked by bicuculline or SR95531, and are markedly less sensitive to picrotoxin. They are also insensitive to modulation by benzodiazepines and barbiturates (Qian and Dowling, 1993; Bormann and Feigenspan, 1995; Johnston, 1996b). GABA ${ }_{C}$ receptors are assembled from $\rho$ subunits $(\rho 1, \rho 2, \rho 3)$, which share some homology with $\mathrm{GABA}_{\mathrm{A}}$ receptor subunits, but do not appear to coassemble with them. $\mathrm{GABA}_{\mathrm{C}}$ receptors have only clearly been demonstrated in the retina (Qian and Dowling, 1994; Enz et al., 1995). Bicuculline-resistant responses to GABA have been reported in several brain regions (Drew et al., 1984; Arakawa and Okada, 1988; Strata and Cherubini, 1994). However, the importance of these receptors outside of the retina has yet to be demonstrated.

The amygdala is intimately involved in emotional behavior, and its role in the generation of anxiety and conditioned fear is well known (Kluver and Bucy, 1939; LeDoux, 1995). Benzodiazepines, which are commonly used for the relief of anxiety, are thought to produce their therapeutic effect by enhancing the action of GABA (Tallman and Gallager, 1985; Costa and Guidotti, 1996). The action of benzodiazepines on GABA receptors within the amygdala is likely to be responsible for the antianxiety action of these agents because binding sites for benzodiazepines are present in the amygdala at high density (Niehoff and Kuhar, 1983; Richards and Möhler, 1984). In this study we have examined the properties of ionotropic GABA receptors in the central amygdala. We find that neurons in the central amygdala 
A
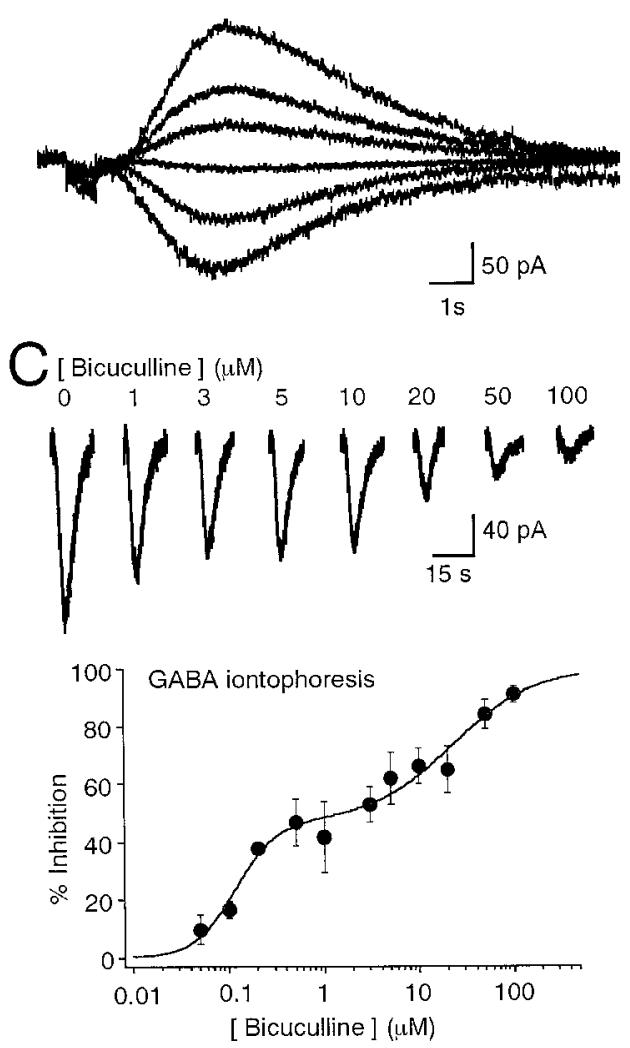

B

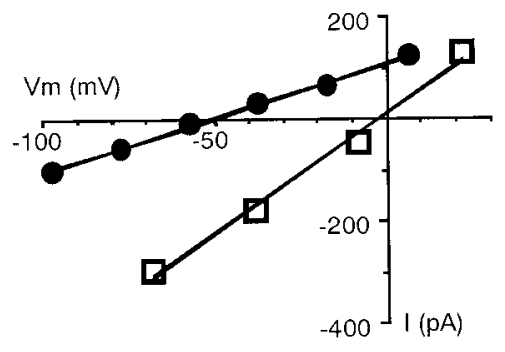

D

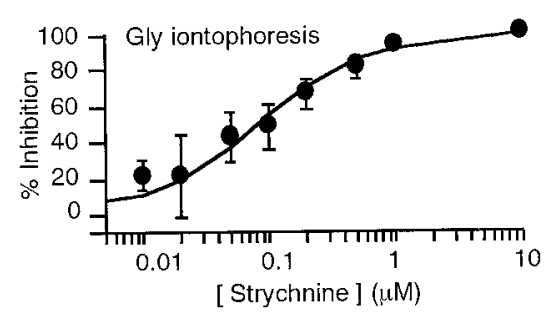

E

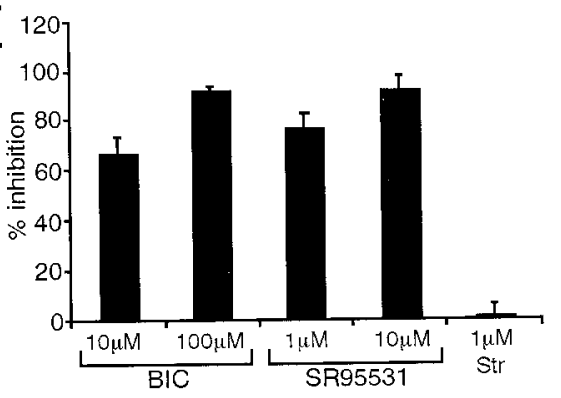

Figure 1. GABA activates two types of ionotropic receptors in the central amygdala. $A$, Responses to iontophoretically applied GABA in a CeL neuron at membrane potential of $-80,-60,-40,-20,0$, and $+10 \mathrm{mV}$ using low-chloride internal solution. $B$, The current-voltage relationship for the records shown in $A$ (filled circles) and responses similarly recorded from a different cell using high-chloride internal solution (open squares). The reversal potential in low-chloride internal was $-50 \mathrm{mV}$, whereas in high internal chloride, it was $-2 \mathrm{mV}$, showing that the GABA activates a chloride-selective current. $C$, Average responses to iontophoretically applied GABA, recorded in increasing concentrations of bicuculline. The graph below plots the percentage inhibition of the GABA response for each dose of bicuculline $(n=3-6$ for each concentration point, except $0.2 \mu \mathrm{M}$, where $n=2)$. The solid line is a fit to the equation $a /\left(1+\left(\mathrm{IC}_{50} / c\right)^{2}\right)+b /\left(1+\left(\mathrm{IC}_{50} / c\right)\right)$ with $\mathrm{IC}_{50}$ values of 0.12 and $23.1 \mu \mathrm{M}(a+$ $b$ was constrained to equal 1$)$. $D$, Inhibition curve for antagonism of the response to iontophoretically applied strychnine ( $n=2-6$ for each concentration point). The solid line is a fit to the equation $1 /(1+$ $\left(\mathrm{IC}_{50} / c\right)$ ) with an $\mathrm{IC}_{50}$ of $0.079 \mu \mathrm{M} . E$, Summary of inhibition of the response to GABA at bicuculline concentrations of 10 and $100 \mu \mathrm{M}(n=11)$, SR95531 at 1 and 10 $\mu \mathrm{M}(n=3)$, and strychnine $(1 \mu \mathrm{M} ; n=3)$. express two types of ionotropic GABA receptor. One is the well known $\mathrm{GABA}_{\mathrm{A}}$ type, which is blocked by bicuculline and is typically modulated by benzodiazepines, barbiturates, and anesthetics. The other type is relatively resistant to bicuculline and picrotoxin, and like $\mathrm{GABA}_{\mathrm{C}}$ receptors is not modulated by barbiturates and anesthetics. However, unlike $\mathrm{GABA}_{\mathrm{C}}$ receptors, these bicuculline-resistant GABA receptors are inhibited by benzodiazepines. Both receptor types contribute to fast inhibitory transmission in the central amygdala.

\section{MATERIALS AND METHODS}

All experiments were done on acute brain slices maintained in vitro. All procedures were in accordance with the Institutional Animal Care and Ethics Committee guidelines. Wistar rats (17- to 20-d-old) were anesthetized with intraperitoneal pentobarbitone $(50 \mathrm{mg} / \mathrm{kg})$, and coronal brain slices $(400 \mu \mathrm{M})$ were prepared using standard methods. Slices were superfused at $200 \mathrm{ml} /$ hr with oxygenated Ringer's solution containing (in mM) $\mathrm{NaCl} 118, \mathrm{KCl} 2.5, \mathrm{NaHCO}_{3} 25$, glucose 10, $\mathrm{NaH}_{2} \mathrm{PO}_{4} 1.2, \mathrm{MgCl}_{2}$ 1.3 , and $\mathrm{CaCl}_{2} 2.5$, in a bath volume of $1 \mathrm{ml}$. Kynurenic acid $(2 \mathrm{mM})$ or CNQX $(10 \mu \mathrm{M})$ and D-APV $(30 \mu \mathrm{M})$ were included in the external solution to block glutamatergic receptors. In other experiments (our unpublished observations), we have confirmed that at these concentrations these compounds completely block glutamatergic synaptic transmission. Tetrodotoxin $(0.5 \mu \mathrm{M})$ was added to the Ringer's solution to block synaptic transmission during experiments with iontophoretically applied GABA. Whole-cell recordings were made from neurons in the lateral division of the central amygdala $(\mathrm{CeL})$ or from pyramidal neurons in the CA1 region of the hippocampus using the "blind" approach. Borosilicate glass electrodes (3-5 M $\Omega$ ) were filled with a cesium-based internal solution to eliminate the effects of $\mathrm{GABA}_{\mathrm{B}}$ receptors. The solution was either high-chloride, containing (in $\mathrm{mM}$ ) $\mathrm{CsCl} 130, \mathrm{MgCl}_{2}$ 1, EGTA 10, HEPES 10, $\mathrm{Mg}_{2}$ ATP 2, and $\mathrm{Na}_{3}$ GTP 0.2 (pH 7.3 with $\mathrm{CsOH}, 290$ $\mathrm{mOsm}$ ), or low-chloride, containing (in $\mathrm{mM}$ ) cesium gluconate 107.5, CsCl 17.5, $\mathrm{NaCl}$ 8, HEPES 10, BAPTA $10, \mathrm{Mg}_{2}$ ATP 2, and $\mathrm{Na}_{3}$ GTP 0.2 ( $\mathrm{pH} 7.3$ with $\mathrm{CsOH}, 290 \mathrm{mOsm}$ ). Membrane potentials recorded were corrected for a junction potential of +17 and $-10 \mathrm{mV}$ for the high- chloride and low-chloride internals, respectively. Normalized $I-V$ relations were constructed by normalizing the current measured at a holding potential of $-80 \mathrm{mV}$. IPSCs were evoked electrically using stainless steel bipolar stimulating electrodes (Frederick Haer) placed near the lateral border of the $\mathrm{CeL}$ or near stratum pyramidale in the CA1 region of the hippocampus. Stimuli were $10-30 \mathrm{~V}$ in amplitude and $50 \mu \mathrm{sec}$ in duration. Iontophoresis pipettes $(>5 \mathrm{M} \Omega$ ) were filled with either $300 \mathrm{~mm}$ GABA (pH 3) or $300 \mathrm{~mm}$ glycine $(\mathrm{pH} 3)$ and placed adjacent to recorded neurons in CeL. Negative retention current $(50-100 \mathrm{nA})$ and positive ejection current (100-200 nA; 0.1-1 sec duration) were generated by a Dagan 6400 iontophoresis unit. Signals were filtered $(5 \mathrm{kHz})$ and amplified using an Axopatch 1D amplifier (Axon Instruments, Foster City, $\mathrm{CA}$ ), digitized at $10 \mathrm{kHz}$ (Instrutech, ITC 16), and recorded and analyzed using Axograph 4.0 software (Axon Instruments) on a Macintosh computer. Series resistance (5-30 M $\Omega$ ) was monitored online throughout the experiment, and experiments were rejected if resistance changed by $>10 \%$. No series resistance compensation was used.

All values are expressed as mean \pm SEM, and all statistical comparisons were done using Student's $t$ test. Drugs used were CNQX (Tocris Cookson), bicuculline methiodide, D-APV, propofol (Research Biochemicals, Natick, MA), kynurenic acid, picrotoxin (Sigma, St. Louis, MO), tetrodotoxin (Alamone Laboratories, Jerusalem, Israel), diazepam (a gift from Prof. P. Gage), 1,2,5,6-tetrohydropyridine-4yl)methylphosphinic acid (TPMPA), flurazepam, Ro 15-1788 (gifts from Associate Prof. G. A. R. Johnston), and pentobarbitone (Bomac Laboratories).

\section{RESULTS}

Whole-cell recordings were made from neurons in the CeL. Iontophoretic application of GABA evoked a current that reversed at the chloride equilibrium potential (Fig. $1 A, B$ ). Bath application of the competitive $\mathrm{GABA}_{\mathrm{A}}$ receptor antagonist bicuculline methiodide (BIC) blocked the GABA-activated current in a manner that was best fit assuming two binding sites with $\mathrm{IC}_{50}$ values of 0.12 and $23.1 \mu \mathrm{M}$ (Fig. 1C). Similar results were also obtained with another competitive GABA $_{\mathrm{A}}$ antagonist SR95531 
(Hamann et al., 1988). On average, $10 \mu \mathrm{M}$ BIC blocked the GABA-activated current by $65 \pm 6 \%$, and $100 \mu \mathrm{M}$ by $92 \pm 3 \%$ $(n=11$; Fig. $1 E$ ); 1 and $10 \mu \mathrm{M}$ SR95531 blocked the iontophoretic current by $77 \pm 6$ and $93 \pm 6 \%(n=3)$, respectively. These results suggest that two types of ionotropic GABA receptor are present on CeL neurons. To rule out the possibility that the low sensitivity of the GABA response might be caused by inadequate access of the bath-applied antagonists to their site of action, we examined a block of iontophoretically applied glycine by the selective antagonist strychnine. Glycine activated a chloridemediated current in all cells tested (data not shown). Strychnine blocked this current at a single, high-affinity site with an $\mathrm{IC}_{50}$ of $79 \mathrm{~nm}$ (Fig. 1D), close to the reported $\mathrm{IC}_{50}$ for strychnine in isolated cells and membrane patches (Shirasaki et al., 1991; Jonas et al., 1998). At $10 \mu \mathrm{M} \mathrm{BIC,} \mathrm{the} \mathrm{contribution} \mathrm{of} \mathrm{the} \mathrm{high-affinity}$ $\mathrm{BIC}$ sites to the GABA response will be negligible. We therefore used this concentration of BIC to examine the properties of the BIC-resistant GABA response.

The relative insensitivity of the GABA response to BIC and SR95531 suggests that a $\mathrm{GABA}_{C}$ like receptor might be present. $\mathrm{GABA}_{\mathrm{C}}$ receptors can be blocked by high concentrations of picrotoxin (Polenzani et al., 1991) and the selective antagonist TPMPA (Ragozzino et al., 1996). In confirmation of this, we found that the GABA response resistant to BIC was blocked by $88 \pm 1 \%$ by $100 \mu \mathrm{M}$ picrotoxin $(n=3)$ and by $73 \pm 1 \%$ by $60 \mu \mathrm{M}$ TPMPA ( $n=3$; Fig. 2 ). These results show that iontophoretically applied GABA activates two pharmacologically distinct recep-

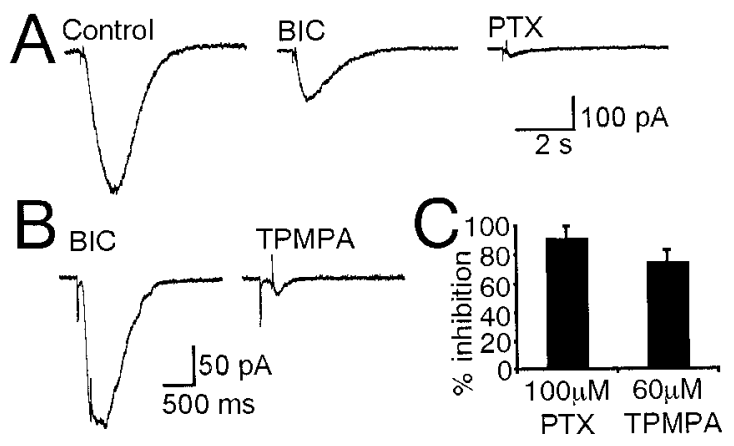

Figure 2. $\mathrm{GABA}_{\mathrm{C}}$-like receptors are present in the central amygdala. $A$, Responses to iontophoretically applied GABA recorded in control, $10 \mu \mathrm{M}$ bicuculline, and $100 \mu \mathrm{M}$ picrotoxin. $B$, The trace on the left is the response to iontophoretically applied GABA in the presence of $10 \mu \mathrm{M}$ BIC. This current is blocked by application of the selective $\mathrm{GABA}_{\mathrm{C}}$ antagonist TPMPA $(60 \mu \mathrm{M})$. $C$, Summary data showing the average reduction of the BIC-resistant response by picrotoxin and TPMPA.

tors. One has a high affinity for BIC and SR95531, and represents activation of $\mathrm{GABA}_{\mathrm{A}}$ receptors, the other is relatively resistant to BIC and SR95531 but is antagonized by TPMPA.

We next asked if these two types of GABA receptor were also activated by synaptically released GABA. Stimulation of local afferents in the presence of glutamatergic antagonists evoked an IPSC that reversed near the chloride equilibrium potential (Fig. $3 A, B)$, showing that it is a chloride-selective current. Application
Figure 3. GABAergic inhibitory synaptic currents in the central amygdala are not blocked by low doses of bicuculline or picrotoxin. $A$, Synaptic currents in response to local electrical stimulation in the presence of blockers of glutamatergic receptors (see Materials and Methods) recorded at membrane potentials of -80 , $-60,-40,-20,0$, and $10 \mathrm{mV}$ using lowchloride internal solution. $B$, Normalized current-voltage relationships for synaptic currents recorded using low-chloride (closed circles) $(n=4)$ and high-chloride internal solutions (open squares) $(n=2)$. The reversal potential in low-chloride internal was $-52 \mathrm{mV}$, whereas in highinternal chloride it was $0 \mathrm{mV}$. C, Average CeL IPSCs recorded in control, in $10 \mu \mathrm{M}$ bicuculline, and in $100 \mu \mathrm{M}$ bicuculline. The IPSC was blocked to $67 \pm 3 \%$ of control by $10 \mu \mathrm{M}$ and $87 \pm 3 \%$ in $100 \mu \mathrm{M}$ BIC. $D$, IPSCs recorded in control, in 25 $\mu \mathrm{M}$ picrotoxin $(P T X)$, and $100 \mu \mathrm{M}$ PTX. IPSC amplitude was blocked by $64 \pm 0 \%$ in $25 \mu \mathrm{M}$ PTX. $E$, Summary of effects of antagonists bicuculline and picrotoxin on IPSC peak amplitude recorded from $\mathrm{CeL}$ neurons ( filled columns) or from CA1 pyramidal neurons (open columns) $(n=5,3$, $3,7,5$, and 4 , respectively).
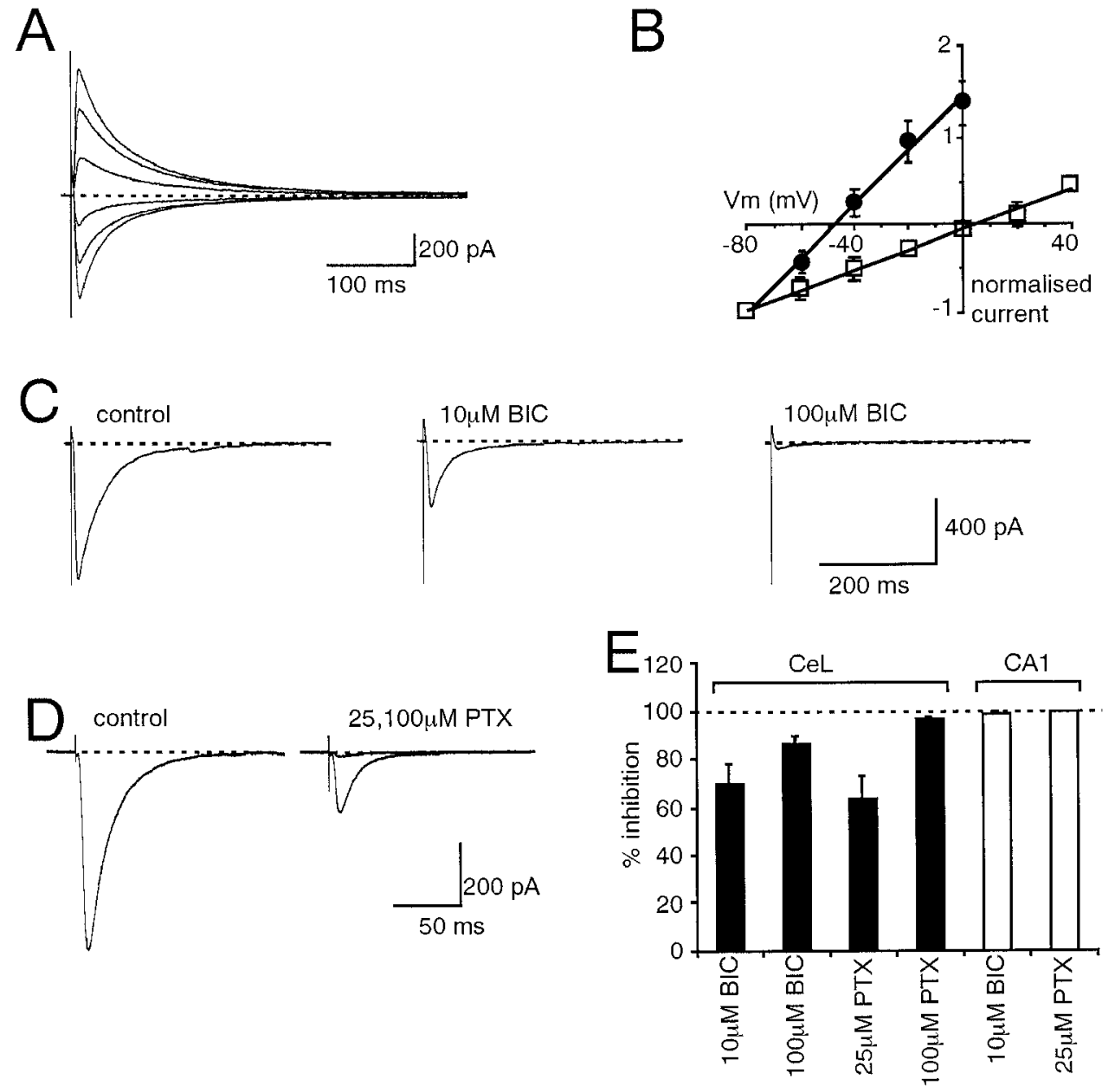

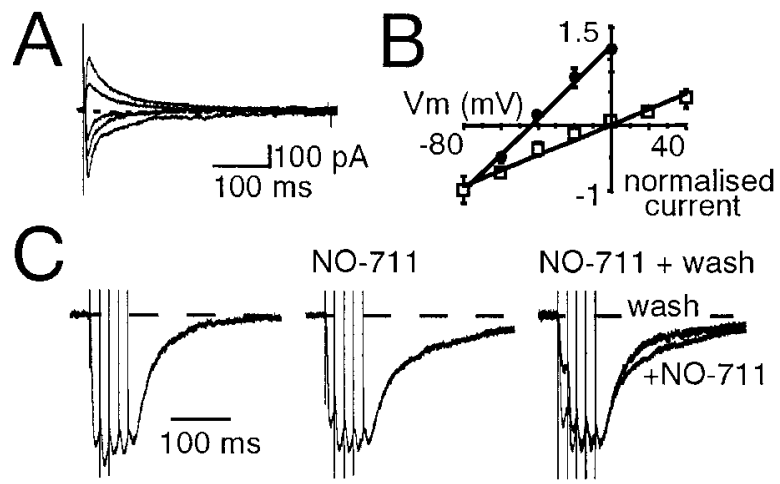

Figure 4. A, Synaptic currents recorded in the presence of $10 \mu \mathrm{M}$ bicuculline at membrane potentials of $-60,-40,-20,0$, and $+10 \mathrm{mV}$ using low-chloride internal solution. $B$, Normalized current-voltage relationship for IPSCs recorded in $10 \mu \mathrm{M}$ bicuculline using low-chloride (closed circles $)(n=4)$ and high-chloride internal solutions (open squares) $(n=6)$. The reversal potential in low-chloride internal was $-44 \mathrm{mV}$, whereas in high-internal chloride it was $0 \mathrm{mV}$. $C$, The GABA uptake blocker NO-711 slows the decay of IPSCs. Each panel shows a train of five IPSCs at stimulated at $20 \mathrm{~Hz}$. Application of NO-711 slows the decay of the synaptic current; after washout of NO-711, the decay returns back to the control response.

of bicuculline at a concentration that abolishes inhibitory transmission at $\mathrm{GABA}_{\mathrm{A}}$ synapses $(10 \mu \mathrm{M})$ (Jonas et al., 1998) only reduced IPSC amplitude to $67 \pm 3 \%$ of the control response $(n=$ 19; Fig. $3 C, E)$. Raising the concentration of BIC to $100 \mu \mathrm{M}$ further blocked the IPSC to $87 \pm 3 \%(n=4)$ of control. Another $\mathrm{GABA}_{\mathrm{A}}$ antagonist picrotoxin was also ineffective in blocking the IPSC; $25 \mu \mathrm{M}$ picrotoxin reduced IPSC amplitude to $63.6 \pm 9.1 \%$ of control $(n=3)$, and $100 \mu \mathrm{M}$ picrotoxin reduced it to $96.7 \pm$ $0.5 \%(n=7$; Fig. $3 D)$. For comparison, $\mathrm{GABA}_{\mathrm{A}}$ receptormediated IPSCs recorded in the CA1 region of the hippocampus were inhibited by $98.3 \pm 0.6 \%(n=5)$ in $10 \mu \mathrm{M} \mathrm{BIC}$ and by $99.1 \pm$ $0.3 \%(n=4)$ with $25 \mu \mathrm{M}$ picrotoxin (Fig. $3 E$ ). Thus in the central amygdala, a component of the inhibitory synaptic current is resistant to block by bicuculline and picrotoxin.

The BIC-resistant IPSC was a chloride-selective current as it reversed near the chloride equilibrium potential (Fig. 4A,B). It was unaffected by the glycine receptor antagonist strychnine (1 $\mu \mathrm{M} ; n=3)$ or the $\mathrm{GABA}_{\mathrm{B}}$ antagonist CGP58854 (20 $\left.\mu \mathrm{M} ; n=3\right)$. Application of the GABA uptake inhibitor NO711 $(n=3)$ slowed its decay (Fig. $4 C$ ), confirming that it is mediated by the release of GABA. Thus, as with iontophoretic application of the GABA, a component of the current activated by synaptically released GABA is resistant to blockade by BIC and picrotoxin.

We next tested if the BIC-resistant IPSC was caused by activation of $\mathrm{GABA}_{\mathrm{C}}$ receptors. TPMPA reversibly inhibited the BIC-resistant IPSC (Fig. 5A,B) in a dose-dependent manner with an $\mathrm{IC}_{50}$ of $18 \mu \mathrm{M}(n=5)$. Consistent with previous results (Ragozzino et al., 1996) the $\mathrm{GABA}_{\mathrm{A}}$-receptor IPSC recorded in area CA1 was unaffected by $60 \mu \mathrm{M}$ TPMPA (Fig. $5 B ; n=7$ ). Because $\mathrm{GABA}_{\mathrm{C}}$ receptors are relatively insensitive to barbiturates, anesthetics, and benzodiazepines we next tested the actions of these agents on the BIC-resistant IPSC. In each case, we compared the action of these agents on the BIC-resistant IPSC with their effects on the $\mathrm{GABA}_{\mathrm{A}}$-mediated IPSC recorded from pyramidal neurons in the CA1 region of the hippocampus. Propofol, an intravenous anesthetic agent that enhances $\mathrm{GABA}_{\mathrm{A}}$ receptor responses (Manuel and Davies, 1998) increased the half-

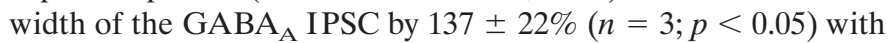
little effect on the peak amplitude. In contrast, propofol had no significant effect on either the peak amplitude or the half width of the BIC-resistant IPSC in the $\mathrm{CeL}(n=3$; Fig. $5 C, D)$. The barbiturate pentobarbitone also had a reduced effect on the BIC-resistant IPSC. Pentobarbitone $(25 \mu \mathrm{M})$ increased the half width of $\mathrm{GABA}_{\mathrm{A}}$-receptor mediated IPSCs by $166 \pm 29 \%(n=$ $4 ; p<0.001)$ with no change in amplitude. In contrast, neither the amplitude nor the half-width of the BIC-resistant IPSC were significantly affected by pentobarbitone. Peak amplitude was re-
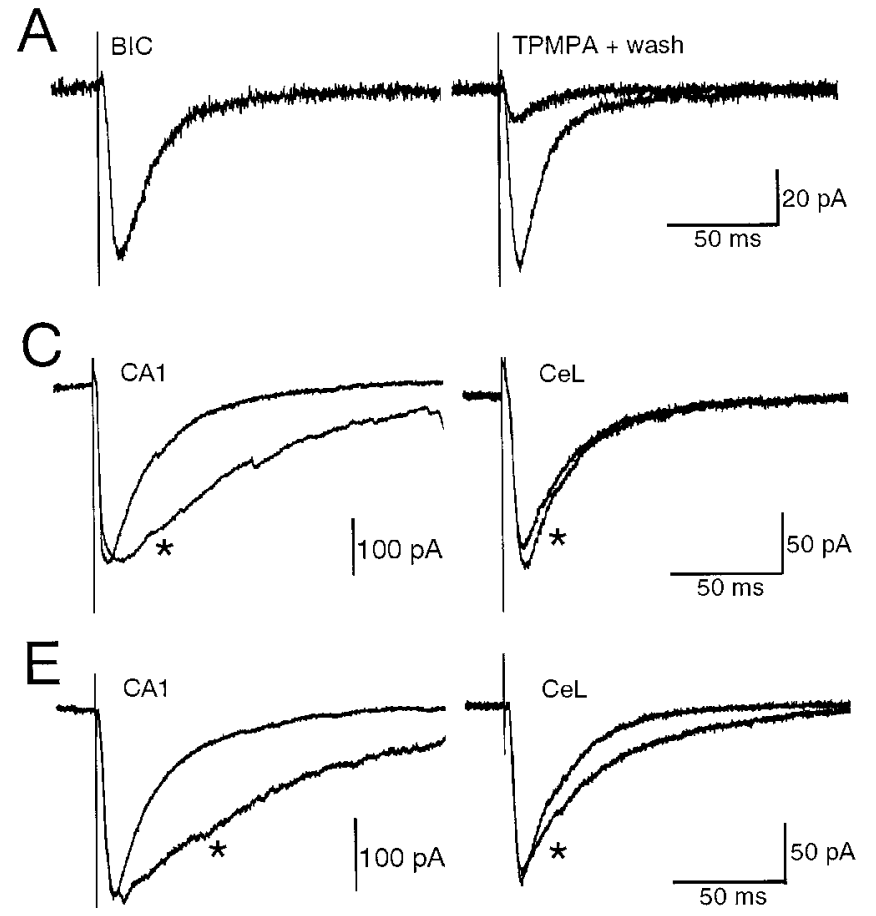

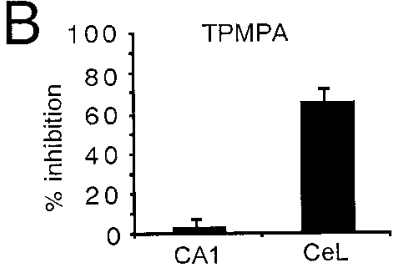

D
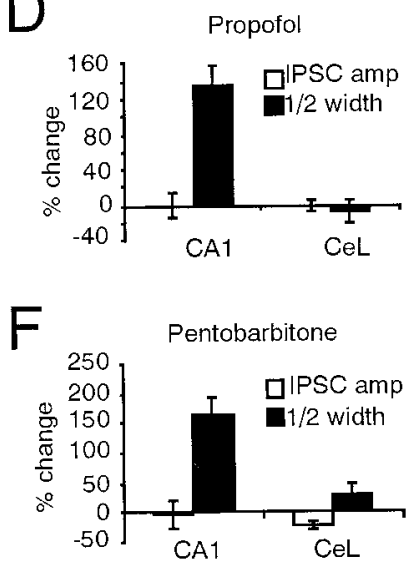

Figure 5. $\mathrm{GABA}_{\mathrm{C}}$ receptors are insensitive to general anesthetics and barbiturates. $A$, The IPSCs recorded in the presence of $10 \mu \mathrm{M}$ bicuculline are reversibly blocked by TPMPA $(60 \mu \mathrm{M})$. $B$, Summary data for the effect of TPMPA on IPSCs recorded from neurons the $\mathrm{CeL}$ and at $\mathrm{GABA}_{\mathrm{A}}$ synapses recorded in pyramidal neurons in the CA1 region of the hippocampus. TPMPA $(60 \mu \mathrm{M})$ reduced the IPSC in the CeL by $65 \pm 8 \%(n=6)$, but had no effect on IPSCs in area CA1 ( $3 \pm$ $4 \% ; n=7)$. $C, D$, Propofol $(10 \mu \mathrm{M})$ slowed the decay of IPSCs in area CA1 (137 \pm $22 \% ; n=3$ ) with no effect on peak amplitude, but had no effect on BIC-resistant IPSCs in the CeL. Traces recorded in the presence of propofol are indicated by an asterisk. E, F, Pentobarbitone $(25 \mu \mathrm{M})$ prolonged the decay of IPSCs in area CA1 (half decay $166 \pm 29 \%$ of control; $n=4$ ) while having relatively little effect on BIC IPSCs in the CeL (half decay $32 \pm 29 \%$ of control; $n=4)$. Traces recorded in the presence of pentobarbitone are indicated by an asterisk. 
Figure 6. Diazepam and flurazepam inhibit $\mathrm{GABA}_{\mathrm{C}}$ receptors in the central amygdala. $A$, The effect of flurazepam on the BIC-resistant IPSC. Flurazepam (1 $\mu \mathrm{M})$ reduced the peak amplitude (37 \pm $5 \%$ of control; $n=9$ ) with no effect on the kinetics of the current. $B$, The benzodiazepine site antagonist Ro15-1788 (1 $\mu \mathrm{M})$ has no effect on IPSC amplitude but blocks the inhibitory effect of flurazepam. After washout of Ro15-1788, a second application of flurazepam now inhibits the IPSC. Individual records taken from the times indicated are shown above. $C$, Summary data showing the effects of flurazepam and diazepam on BIC-resistant IPSCs in control conditions $(n=9)$ and Ro $15-1788(n=3)$. D, The effects of benzodiazepines are postsynaptic because diazepam $(10 \mu \mathrm{M})$ blocks the bicucullineresistant response to iontophoretically applied GABA by $27 \pm 8 \%(n=5)$.
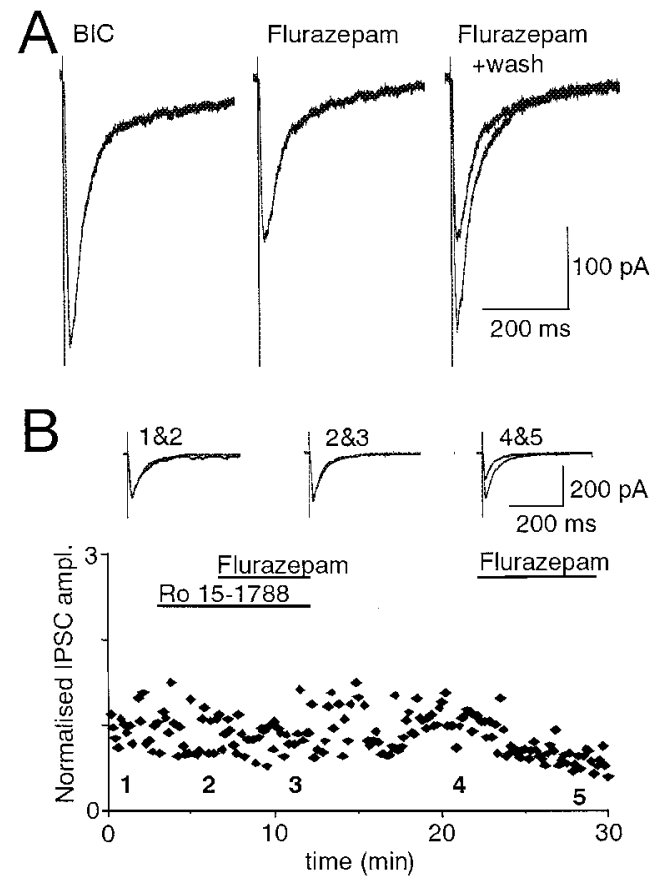

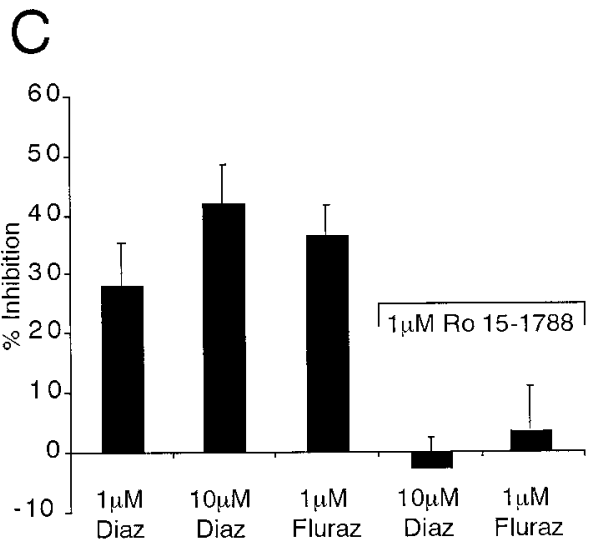

$\mathrm{D}$
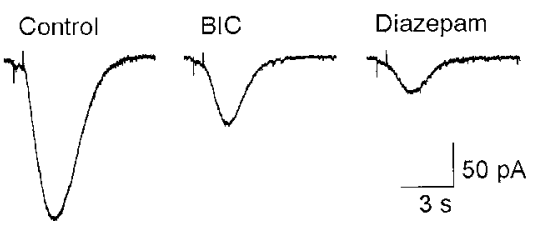

duced by $21.2 \pm 7.4 \%(p=0.16)$, and half-width increased by $32 \pm 16 \%(n=3 ; p=0.07$; Fig. $5 E, F)$.

The 1,4-benzodiazepines act as positive modulators of some $\mathrm{GABA}_{\mathrm{A}}$ receptors (MacDonald and Olsen, 1994; Costa, 1998) by increasing the affinity of the receptor for GABA (Lavoie and Twyman, 1996), whereas $\mathrm{GABA}_{\mathrm{C}}$ receptors are insensitive to these agents. In the CeL, flurazepam $(1 \mu \mathrm{M})$ reduced the amplitude of the BIC-resistant IPSC by $37 \pm 5 \%(n=9$; Fig. $6 A)$. Diazepam $(1 \mu \mathrm{M})$, another 1,4 benzodiazepine, reduced the amplitude of the BIC-resistant IPSC by $28 \pm 7 \%$, and $10 \mu \mathrm{M}$ diazepam reduced it by $42 \pm 5 \%(n=5$; Fig. $6 C)$. This effect was fully antagonized by the benzodiazepine receptor antagonist Ro 15-1788 (Hunkeler et al., 1981) (Fig. 6C), showing that it was not a nonspecific action of these benzodiazepines. There was no effect on the kinetics of the IPSC with either diazepam or flurazepam (Fig. 6A,C). To confirm that the effects of the benzodiazepines on IPSC amplitude were caused by their postsynaptic actions on GABA receptors, we tested the action of diazepam on iotophoretically applied GABA. Diazepam $(10 \mu \mathrm{M})$ reduced the amplitude of the BIC-resistant GABA-evoked current by $27 \pm 8 \%(n=5$; Fig. $6 D)$, showing that the effects of diazepam are postsynaptic.

We performed two control experiments to ensure that the benzodiazepines were active at $\mathrm{GABA}_{\mathrm{A}}$ receptors in our hands. First, we checked the action of these drugs on $\mathrm{GABA}_{\mathrm{A}}$ synapses recorded from CA1 neurons in the hippocampus. Diazepam (1 $\mu \mathrm{M})$ increased the amplitude of hippocampal $\mathrm{GABA}_{\mathrm{A}}$ receptormediated IPSCs by $34 \pm 16 \%$ and its half decay by $17 \pm 12 \%$ $(n=5)$, and at $10 \mu \mathrm{M}$, the IPSC amplitude and half width increased by $41 \pm 16$ and $28 \pm 18 \%$, respectively (data not shown). These effects are typical of the actions of benzodiazepines at $\mathrm{GABA}_{\mathrm{A}}$ synapses (Otis and Mody, 1992; Zhang et al., 1993). Second, we isolated the $\mathrm{GABA}_{\mathrm{A}}$-mediated IPSC in CeL neurons by performing experiments in the presence of TPMPA. TPMPA $(60 \mu \mathrm{M})$ blocked the control IPSC by $27 \pm 2 \%(n=4)$. In the presence of TPMPA, bicuculline $(10 \mu \mathrm{M})$ blocked the IPSC (96 $\pm 1 \%$ of control; Fig. $7 A$ ), confirming it was caused by activation of $\mathrm{GABA}_{\mathrm{A}}$ receptors. Application of flurazepam in the presence of TPMPA had no effect on the peak amplitude but increased the half width of the IPSC by $121 \pm 5 \%(n=3$; Fig. $7 B$ ), showing that $\mathrm{GABA}_{\mathrm{A}}$ receptors that contribute to the IPSC have a typical pharmacology.

\section{DISCUSSION}

We have shown that in the CeL, both exogenously applied GABA and synaptically released GABA activate two types of ionotropic GABA receptor. One is a classical $\mathrm{GABA}_{\mathrm{A}}$ receptor, inhibited by $\mathrm{BIC}$ and positively modulated by benzodiazepines. The other is relatively insensitive to the classical $\mathrm{GABA}_{\mathrm{A}}$ receptor antagonists bicuculline and picrotoxin. This $\mathrm{BIC}$-insensitive response is blocked by the $\mathrm{GABA}_{\mathrm{C}}$ antagonist TPMPA. Furthermore, like $\mathrm{GABA}_{\mathrm{C}}$ receptors, the $\mathrm{BIC}$-insensitive component is not affected
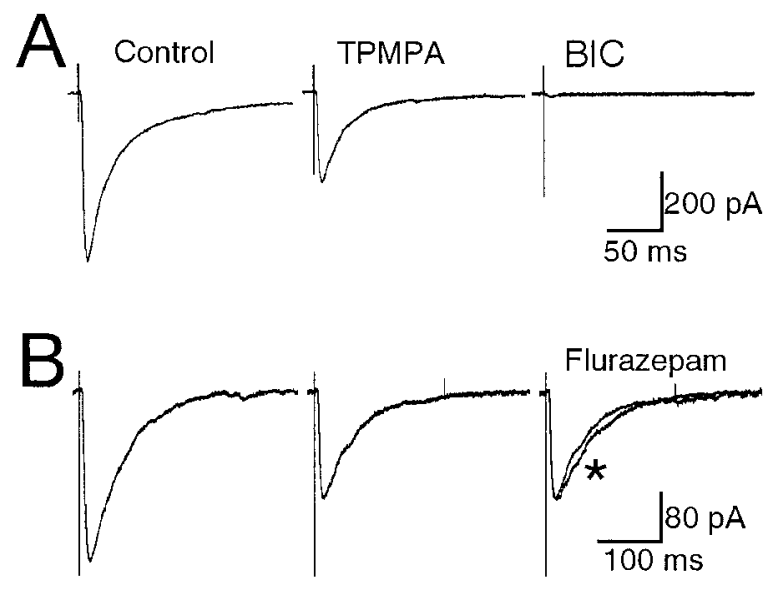

Figure 7. Pharmacology of $\mathrm{GABA}_{\mathrm{A}}$ receptors in the CeL. GABA receptors were isolated by blocking $\mathrm{GABA}_{\mathrm{C}}$ receptors with TPMPA (60 $\mu \mathrm{M})$. $A$, The IPSC remaining in the presence of TPMPA is effectively inhibited by $10 \mu \mathrm{M}$ bicuculline. $B$, The GABA $_{\mathrm{A}}$ receptor-mediated IPSC is positively modulated by benzodiazepines. Flurazepam had no effect on peak amplitude but increased the half width by $121 \pm 5 \%$. 
by the anesthetic propofol or by the barbiturate pentobarbitone, agents that potentiate the response to GABA at $\mathrm{GABA}_{\mathrm{A}}$ receptors. However, unlike $\mathrm{GABA}_{\mathrm{C}}$ receptors, the $\mathrm{BIC}$-resistant response is inhibited by the benzodiazepines diazepam and flurazepam.

$\mathrm{BIC}$ is a competitive antagonist of GABA, and it is possible that the "BIC-resistant" response simply represents the current caused by activation of GABA receptors as BIC unbinds in the presence of GABA. This is unlikely for several reasons. (1) The GABA response resistant to $\mathrm{BIC}$ had a pharmacological profile different to that of $\mathrm{GABA}_{\mathrm{A}}$ receptors. (2) If $\mathrm{BIC}$ was being competed off, we would expect that the response in the presence of BIC would have a slower rising phase than the control response. However, neither the iontophoretic response to GABA nor the synaptic current remaining in BIC had slower rising phases. (3) If BIC was unbinding, then we would expect that the fractional block of the synaptic current by BIC would be significantly higher than during iontophoresis because GABA will be present for a much shorter duration when it is released synaptically (Clements, 1996). However, the fractional block of the GABA response during iontophoretic application of GABA was very similar to that of the synaptic current (34 vs 33\%). (4) The much higher affinity antagonist SR95531 also revealed two types of GABA response. Thus, we are confident that the BIC-resistant response represents activation of a different type of GABA receptor.

$\mathrm{GABA}_{\mathrm{C}}$ receptors were first found in the retina where they have been extensively characterized in a number of species in bipolar and horizontal cells (Bormann and Feigenspan, 1995). These receptors are thought to be assembled from $\rho$ subunits of which three genes, $\rho 1, \rho 2$, and $\rho 3$ have been found (Cutting et al., 1991; Shimada et al., 1992). Homomeric $\rho 1$ receptors are sufficient to form ion channels with properties consistent with those of $\mathrm{GABA}_{\mathrm{C}}$ receptors. However, $\rho 1$ and $\rho 2$ can also assemble as heterooligomers with properties different from those of homomeric channels (Enz and Cutting, 1999), raising the possibility of some diversity in $\mathrm{GABA}_{\mathrm{C}}$ receptors. Although $\rho$ subunits have been detected in brain (Enz et al., 1995; Boue-Grabot et al., 1998; Enz and Cutting, 1999), and BIC-resistant responses to GABA have also been reported (Drew et al., 1984; Arakawa and Okada, 1988; Strata and Cherubini, 1994), the presence of $\mathrm{GABA}_{\mathrm{C}}$ receptors in central neurons has not been clearly demonstrated (Johnston, 1996b). Our results suggest the presence of a GABA $\mathrm{C}^{-}$ like receptor in the central amygdala. It is not known whether neurons in the CeL express $\rho$ subunits. However, it is unlikely that the BIC-insensitive responses we have recorded are caused by receptors assembled from $\rho$ subunits alone as such receptors, like GABA $_{C}$ receptors, are unaffected by bicuculline and benzodiazepines (Bormann and Feigenspan, 1995), whereas the BICresistant response the $\mathrm{CeL}$ is blocked by high concentrations of $\mathrm{BIC}$ and is negatively modulated by benzodiazepines.

$\mathrm{GABA}_{\mathrm{A}}$ receptors are assembled from 15 different subunits. These subunits can form functional channels as homomers or as heteromultimers of various subunit combinations. However, $\alpha, \beta$, and $\gamma$ subunits are required to reproduce the full pharmacological profile of native GABA receptors. Both $\alpha$ and $\gamma$ subunits determine benzodiazepine sensitivity. The responses of receptors containing $\gamma$ subunits are amplified by benzodiazepines, whereas receptors lacking $\gamma$ subunits are insensitive to benzodiazepines. Receptors containing and $\alpha 6$ subunits are also benzodiazepineinsensitive (Costa, 1998). In situ hybridization studies have shown that $\alpha 1, \alpha 2, \alpha 3, \beta 1, \beta 2, \beta 3, \gamma 1, \gamma 2$, and $\gamma 3$ subunits are expressed in the central amygdala (Wisden et al., 1992). Thus, subunits that could produce GABA receptors positively modulated by benzodiazepines are present, consistent with the presence of such receptors on $\mathrm{CeL}$ neurons. Although inverse agonists of GABA receptors are known, no GABA receptor examined so far has been found to be negatively modulated by the 1,4 benzodiazepines (Costa, 1998). The presence of the $\gamma 1$ subunit is known to produce atypical benzodiazepine pharmacology turning the inverse agonist Ro15-4513 into an agonist (Wafford et al., 1993). Furthermore, small changes in the primary structure of receptor subunits can dramatically change the pharmacological profile of that receptor (Wang et al., 1995; Valfa and Schofield, 1998). Thus, one possibility is that the receptors we have characterized here are assembled from variants of known $\mathrm{GABA}_{\mathrm{A}}$ receptor subunits. Alternatively, it is not inconceivable that an as yet undiscovered subunit might confer the unusual benzodiazepine pharmacology in CeL neurons. The fact that the effect of benzodiazepines was inhibited by Ro 15-1788 suggests that the binding site for these agents on $\mathrm{GABA}_{\mathrm{C}}$-like receptors might be the same as in other, positively modulated $\mathrm{GABA}_{\mathrm{A}}$ receptors.

The amygdala is a key structure in the processing of emotional information (LeDoux, 1996) and has been implicated in the genesis of fear responses. Dysfunction of the amygdala has been suggested to underlie anxiety-type disorders (Davis, 1992; LeDoux, 1995). The benzodiazepines, which are widely used in the treatment of such disorders, are thought to act by enhancing the actions of GABA at $\mathrm{GABA}_{\mathrm{A}}$ receptors (Tallman and Gallager, 1985; Costa and Guidotti, 1996). The presence of a GABA receptor in the amygdala that is inhibited by benzodiazepines suggests that the actions of these agents in the amygdala are more complex than previously thought. This receptor might be a possible new target in the development of therapeutic agents for disorders involving the amygdala.

\section{REFERENCES}

Arakawa T, Okada Y (1988) Excitatory and inhibitory action of GABA on synaptic transmission in slices of guinea pig superior colliculus. Eur J Pharmacol 158:217-224.

Barnard EA, Skolnick P, Olsen RW, Möhler H, Seighart W, Biggio G, Braestrup C, Bateson AN, Langer SZ (1998) International union of pharmacology. XV. Subtypes of $\gamma$-aminobutyric acidA receptors: classification on the basis of subunit structure and receptor function. Pharmacol Rev 50:291-313.

Bormann J, Feigenspan A (1995) GABA $_{\mathrm{C}}$ receptors. Trends Neurosci 18:515-518.

Boue-Grabot E, Roudbaraki M, Bascles L, Tramu G, Bloch B, Garret M (1998) Expression of GABA receptor $\rho$ subunits in rat brain. J Neurochem 70:899-907.

Clements JD (1996) Transmitter timecourse in the synaptic cleft: its role in central synaptic function. Trends Neurosci 19:163-171.

Costa E (1998) From GABAA receptor diversity emerges a unified vision of GABAergic inhibition. Annu Rev Pharmacol Toxicol 38:321-350.

Costa E, Guidotti A (1996) Benzodiazepines on trial: a research strategy for their rehabilitation. Trends Pharmacol Sci 17:192-200.

Cutting GR, Lu L, O'Hara BF, Kasch LM, Montrose-Rafizadeh C, Donovan DM, Shimada S, Antonarakis SE, Guggino WB, Uhl GR, Kazazian HH (1991) Cloning of the $\gamma$-aminobutyric (GABA) $\rho 1$ cDNA: a GABA receptor highly expressed in the retina. Proc Natl Acad Sci USA 88:2673-2677.

Davis M (1992) The role of the amygdala in fear and anxiety. Annu Rev Neurosci 15:353-375.

Drew CA, Johnston G, Weatherby RP (1984) Bicuculline-insensitive GABA receptors: studies on the binding of (-)-baclofen to rat cerebellar membrane. Neurosci Lett 52:317-321.

Enz R, Cutting GR (1999) $\mathrm{GABA}_{\mathrm{C}}$ receptor $\mathrm{r}$ subunits are heterogeneously expressed in the human CNS and form homo- and heterooligomers with distinct physical properties. Eur J Neurosci 11:41-50. 
Enz R, Brandstätter JH, Hartveit E, Wässle H, Bormann J (1995) Expression of GABA receptor $\mathrm{r} 1$ and $\mathrm{r} 2$ subunits in the retina and brain of the rat. Eur J Neurosci 7:1495-1501.

Hamann H, Desarmenian M, Desaulles E, Bader M, Feltz P (1988) Quantitative evaluation of the properties of a pyridazinyl GABA derivative (SR 95531) as a $\mathrm{GABA}_{\mathrm{A}}$ competitive antagonist. An electrophysiological approach. Brain Res 442:287-296.

Hunkeler W, Möhler H, Pieri L, Polc P, Bonetti EP, Cumin R, Schaffner R, Haefely W (1981) Selective antagonists of benzodiazepines. Nature 290:514-516.

Johnston GAR (1996a) $\mathrm{GABA}_{\mathrm{A}}$ receptor pharmacology. Pharmacol Ther 69:173-198.

Johnston GAR (1996b) GABA $_{C}$ receptors: relatively simple transmittergated ion channels? Trends Pharmacol Sci 17:319-323.

Jonas P, Bischofberger J, Sandkühler J (1998) Corelease of two fast neurotransmitters at a central synapse. Science 281:419-424.

Kluver H, Bucy PC (1939) Preliminary analysis of the temporal lobes in monkeys. Arch Neurol Psychiatr 42:979-100.

Lavoie AM, Twyman RE (1996) Direct evidence for diazepam modulation of GABAA receptor microscopic affinity. Neuropharmacology 9:1383-1392.

LeDoux JE (1995) Emotion: clues from the brain. Annu Rev Psychol 46:209-235.

LeDoux JE (1996) The emotional brain. New York: Simon and Schuster.

MacDonald RL, Olsen RW (1994) GABAA receptor channels. Annu Rev Neurosci 17:569-602.

Manuel NA, Davies CH (1998) Pharmacological modulation of GABAA receptor-mediated postsynaptic potentials in the CA1 region of the rat hippocampus. Br J Pharmacol 125:1529-1542.

Nicoll RA, Malenka RC, Kauer JA (1989) Functional comparison of neurotransmitter receptor subtypes in the mammalian central nervous system. Physiol Rev 70:513-565.

Niehoff DL, Kuhar MJ (1983) Benzodiazepine receptors: localization in rat amygdala. J Neurosci 3:2091-2097.

Otis TS, Mody I (1992) Modulation of decay kinetics and frequency of $\mathrm{GABA}_{\mathrm{A}}$ receptor-mediated spontaneous inhibitory currents in hippocampal neurons. Neuroscience 49:13-32.

Polenzani L, Woodward RM, Miledi R (1991) Expression of mammalian $\gamma$-aminobutyric acid receptors with distinct pharmacology. Proc Natl Acad Sci USA 88:4318-4322.

Qian H, Dowling JE (1993) Novel GABA responses from rod-driven retinalhorizontal cells. Nature 361:162-164.
Qian H, Dowling JE (1994) Pharmacology of novel GABA receptors found on rod horizontal cells of the white perch retina. J Neurosci 14:4299-4307.

Ragozzino D, Woodward RM, Murata Y, Eusebi F, Overman LE, Miledi R (1996) Design and in vitro pharmacology of a selective $\gamma$-aminobutyric $\operatorname{acid}_{\mathrm{c}}$ receptor antagonist. Mol Pharmacol 50:1024-1030.

Richards JG, Möhler H (1984) Benzodiazepine receptors. Neuropharmacology 23:233-242.

Shimada S, Cutting G, Uhl GR (1992) $\gamma$-Aminobutyric acid A or C receptor? $\gamma$-Aminobutyric acid $\rho 1$ receptor RNA induces bicuculline-, barbiturate-, and benzodiazepine-insensitive $\gamma$-aminobutyric acid responses in Xenopus oocytes. Mol Pharmacol 41:683-687.

Shirasaki T, Klee MR, Nakaye T, Akaike N (1991) Differential blockade of bicuculline and strychnine on GABA- and glycine-induced response in dissociated rat hippocampal cells. Brain Res 561:77-83.

Sieghart W (1995) Structure and pharmacology of $\gamma$-aminobutyric acid receptor subtypes. Pharmacol Rev 47:181-234.

Strata F, Cherubini E (1994) Transient expression of a novel type of GABA response in rat CA3 hippocampal neurones during development. J Physiol (Lond) 480:493-503.

Tallman JF, Gallager DW (1985) The GABAergic system: a locus of benzodiazepine action. Annu Rev Neurosci 8:21-44.

Valfa B, Schofield PR (1998) Heritable mutations in the glycine, GABAA, and nicotinic acetylcholine receptors provide new insights into the ligand-gated ion channel receptor superfamily. Int Rev Neurobiol 42:285-332.

Wafford KA, Bain CJ, Whiting PJ, Kemp JA (1993) Functional comparison of the role of $\mathrm{g}$ subunits in recombinant human $\gamma$-aminobutyric $\mathrm{acid}_{\mathrm{A}} /$ benzodiazepine receptors. Mol Pharmacol 44:437-442.

Wang T-L, Hackam A, Guggino WB, Cutting GR (1995) A single amino acid in the $\gamma$-aminobutyric acid $\mathrm{r} 1$ receptors affects competitive and noncompetitive components of picrotoxin inhibition. Proc Natl Acad Sci USA 92:11751-11755.

Wisden W, Laurie DJ, Monyer H, Seeburg PH (1992) The distribution of 13 GABAA receptor subunit mRNAs in the rat brain. I. Telencephalon, diencephalon, mesencephalon. J Neurosci 12:1040-1062.

Zhang L, Weiner JL, Carlen PL (1993) Potentiation of $\gamma$-aminobutyric acid type A receptor-mediated synaptic currents by pentobarbital and diazepam immature hippocampal CA1 neurons. J Pharmacol Exp Ther 266:1226-1235. 